\title{
Polycentric structures nurturing adaptive food quality governance - Lessons learned from geographical indications in the European Union
}

\author{
Marianne Penker ${ }^{a}$, Silvia Scaramuzzi ${ }^{\text {b, }}$, Hanna Edelmann ${ }^{\text {a }}$, Giovanni Belletti ${ }^{c}$, \\ Andrea Marescotti $^{\text {a, }}$, François Casabianca ${ }^{\mathrm{d}}$, Xiomara F. Quiñones-Ruiz ${ }^{\mathrm{a}}$ \\ ${ }^{a}$ Department of Economics and Social Sciences, University of Natural Resources and Life Sciences, Vienna, (BOKU), Austria \\ ${ }^{\mathrm{b}}$ Department of Agricultural, Food and Forestry Systems, University of Florence, Italy \\ ${ }^{\mathrm{c}}$ Department of Economics and Management, University of Florence, Italy \\ ${ }^{\mathrm{d}}$ Institut National de Recherche pour l'Agriculture, l'Alimentation et l'Environnement, INRAE, France
}

\section{A R T I C L E I N F O}

\section{Keywords:}

Geographical indications

Amendments

Product specification

Polycentric governance

Food quality standards

European Union

\begin{abstract}
A B S T R A C T
In contrast to harmonised international food quality standards, local producers of food that is protected as geographical indication can adapt production rules. In a comparative multi-method case study approach, we analyse how constitutional and collective choice rules affect the negotiation of diverse interests and the adaptability of food quality standards in France, Italy and Austria. In France, a national organisation with a plurality of technical expertise guarantees the coherence of geographical indications based on notions of terroir and heritage. Italy's rural development approach secures very elaborated voting rules for producer groups and broader interaction on the regional level to accomplish broadly legitimated decisions. In the Austrian intellectual property rights approach, producers self-define the constitutional and collective choice rules and have the fullest autonomy and responsibility in standard setting. We conclude that polycentric interlinkages across scales and sectors - though delaying adaptation - support the long-term conservation of the products' identity via broad legitimisation. Both, the autonomy of local producers to innovatively adapt to change as well as a strong product identity are key for the long-term viability of geographical indications.
\end{abstract}

\section{Introduction}

The role territorial origin plays for food quality is increasingly permeating research in agricultural and social sciences, as well as public policy. The protection of Geographical Indications (GIs) is a tool that allows producers who have the right to use the indication to prevent its use by a third party whose product does not meet the food quality standards.

Centrally defined international standards, such as organic or Fairtrade (see Reinecke et al., 2012; Schouten and Bitzer, 2015; Spiekermann, 2011), which increasingly govern food quality, can guarantee the same minimum quality worldwide. However, they have also been questioned in terms of their adaptability to change, local contexts, and innovation (Milestad and Darnhofer, 2003; Teil, 2013; Vogl et al., 2005).

As an antithesis to these international standards, GIs - like the sui generis European Union (EU) GI regime - are based on a variety of decentralised defined regulatory frameworks that ensure a link between the product attributes and its place of origin and provide a space for local actors to discuss their own vision of the product (Pick and Marie-Vivien, 2021). In this article, we use France, Italy, and Austria as contrasting cases of GI governance to better understand how differences in governance structures affect the coordination of diverse interests and the adaptability of food quality standards to changing (local) contexts.

Food quality governance - in analogy to diverse governance definitions as summarised by Stoker (2018) - can be understood as creating the conditions for food quality standards that do not rely solely on recourse to government authority and sanction, but are the result of the interaction of public, private, and voluntary sector actors. Therefore, this article scrutinizes the interaction of public, private, and voluntary actors, as well as central government and decentralised autonomous self-governance of food quality. According to Stoker (2018), governance involves some inevitable tensions and dilemmas, such as the blurring of responsibilities and difficulties in accountability, but also the promise of an adaptive approach to learning and experimentation in view of uncertainty and limits of human knowledge and understanding.

With our comparative case study analysis, we address the broader research problem of the adaptability of food quality standards to change

\footnotetext{
* Corresponding author.

E-mail address: silvia.scaramuzzi@unifi.it (S. Scaramuzzi).
} 
(e.g., in demand, climate, technology or policy). Centrally defined, uniform, and equivalent food quality standards, such as those defined by the International Federation of Organic Agriculture Movements (IFOAM), support the diffusion of food quality through economic networks (Teil, 2013). Already at the beginning of this century, Milestad and Darnhofer (2003), who analysed the IFOAM Basic Standard in light of the impact of government regulation and market dynamics, concluded that there is a danger of losing the ability to adapt and learn in organic farming. Debates among organic farming scholars highlight that the rigidity of a regulatory framework required for market exchange is in tension with the flexibility needed to continually redefine food quality and adapt it to new situations (Teil, 2013). Or more pointedly, "equivalence and homogenisation standards kill the possibility of local identification and local adaptation" (Vogl et al., 2005, p. 18). In contrast to the idea of internationally harmonised food quality standards, GIs are diverse because they are collectively defined by thousands of decentralised producer groups worldwide. By linking food quality to specific places, GIs protect and promote the origins, traditions, and unique characteristics of many distinctive products.

This paper focuses on GIs in the EU, and thus on a producer-led approach to GI protection (Pick and Marie-Vivien, 2021). According to the sui generis GI legislation in the EU (Council Regulations (EU) No 2081/92, 510/2006 and 1151/2012), producers themselves define the rules governing the production process, the characteristics of the final product, and the boundaries of the production area. They "objectify" these rules in a so-called product specification (PS) (Mariani et al., 2020). With this PS, producers apply for the GI status, first at the national and then at EU level. The PS is also the main reference document for third party control. After registering their GI, producers are forced to adapt the PS in response to evolving societal, technical, market, environmental, and political conditions or changes within the producer group (Baritaux et al., 2016; Belletti et al., 2015; Mancini and Consiglieri, 2016; Millet and Casabianca, 2019; Quiñones-Ruiz et al., 2018). They can submit applications for PS amendments to national and EU authorities - following basically the same procedures as for GI

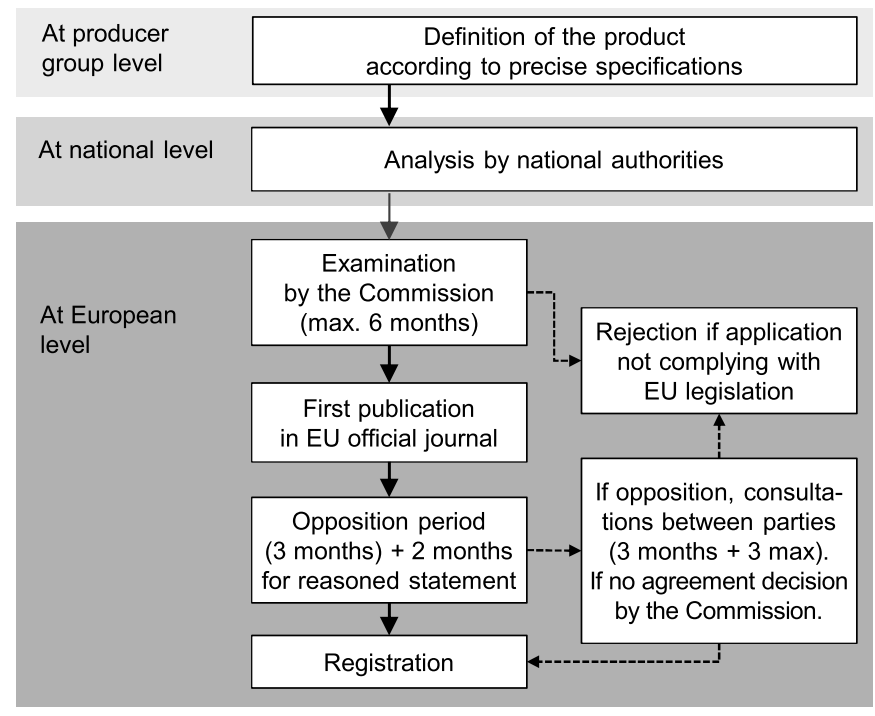

Fig. 1. Multi-level process of GI registration and amendment in the EU (adapted from Quiñones-Ruiz et al., 2016). Note: In case of minor amendments (Regulation (EU) No 1152/2012 Art. 53) a simplified procedure is applied: The Commission only rejects or approves the amendments, assisted by the Agricultural Product Quality Policy Committee, which gives its compulsory opinion (Regulation (EU) No 1152/2012 Art. 57). In case of approval, the Commission will publish the compulsory amended Single Document in the Official Journal of the EU. The reference to the PS publication in the amended Single Document shall lead to the updated version of the PS (Commission Implementing Regulation (EU) No 668/2014Commission Implementing Regulation (EU) No 668/2014). registration (Fig. 1). If no opposition is filed, the GI (and their amendments) will be registered. This common EU frame is implemented very differently in the various Member States, as our analysis of GI amendments in this article will show.

Clark and Kerr (2017) argue that adaptation choices are likely to involve "a move away from traditional production practices, reductions in the specifications of quality, and altering the geographical scope of the GI design". Marescotti et al. (2020) provided insights into the fruit and vegetable sector, where amendments in Italy and Spain led to more flexible regulations, while France showed more diversified approaches. Not only, but particularly in the case of GIs, the long-term success of governing food quality depends on the conservation and careful adaptation of the product identity.

Although GIs are governed at multiple levels (see Fig. 1), producers play the key role in decision-making on PSs, provided they demonstrate the link between product's quality attributes and its place of origin. The combination of multilevel governance and the direct involvement of non-state actors in decision-making is at the core of the concept of polycentric governance (Newig and Koontz, 2014). Originally coined by Polanyi (1951), the concept has been broadly applied, e.g., to social-ecological systems, in part with the expectation that polycentricity could make these systems more sustainable, resilient, and adaptable (Andersson and E. Ostrom, 2008). While bottom-up (producer-led) and top-down (state-driven) approaches to GI protection have been analysed (Pick and Marie-Vivien, 2021; Sylvander, 2004), there is a lack of studies taking a polycentricity perspective to compare different GI approaches within the EU in terms of their adaptability.

This paper aims to: i) compare three different food quality governance structures in Austria, France, and Italy by unpacking the de jure and the de facto rules that shape the interactions of the actors involved in GI amendments; ii) understand how these patterns might affect the coordination of different interests and the adaptability of food quality standards. In Section 2, we introduce the guiding concepts of the paper. In Section 3, we explain the methods for analysing the GI cases, which were selected based on the largest expected difference (Seawright and Gerring, 2008) and the stakeholders interviewed. Finally, we present the results, followed by a discussion and conclusion.

\section{Polycentric governance and the three levels of rules}

Polanyi (1951) coined a spontaneous or polycentric order as "one where many elements are capable of making mutual adjustments for ordering their relationships with one another within a general system of rules where each element acts with independence of other elements". The definition has been more recently reported and specified by V. Ostrom (1999, p. 57).

Building on this, E. Ostrom (2001) specified polycentric systems as the organizational nexus of small-, medium-, and large-scale democratic units or entities, in which each one might exercise considerable autonomy to design and enforce rules within a bounded scope of authority for a determined geographical zone. Based on the institutional analysis and development framework that also proposes analytic distinctions for polycentricity (summarised by McGinnis, 2011), we differentiate between three levels of rules:

- Constitutional choice rules determine who will take part in collective choice decision-making, i.e. the actors and organisations involved and their responsibilities in food quality governance (rules codified in EU and national legislation as well as informal practices) (see Tables $3-5$ in the results section).

- Collective choice rules define how food quality standards are created and modified by those actors authorised to participate in the collective decision-making according to constitutional choice rules. Collective choice rules shape the processes of decision-making about quality standards and the interactions of the actors involved, including horizontal interactions among different producers as well 
as vertical interactions between producer groups acting autonomously and higher level public authorities (Andersson and E. Ostrom, 2008). These interactions may be unilateral exchanges (e.g., an approval needed in a hierarchical interaction with national and European authorities), competitive (market/consumer decides), or cooperative (e.g., horizontal across producer groups or sectors, or vertical consultative exchange and learning). Rules might be codified in national or EU legislation or may represent informal practices. Both formal and informal interactions are depicted in Figs. 2-4.

- Operational choice rules define how food should or should not be produced, processed, prepared, packaged, and marketed. They are formally codified in the PS, or informal practices that may complement or deviate from the formal rules.

We want to distinguish the formal rules on paper and the actual rules in use (practices and routines) applied at these three levels (McGinnis, 2011). In a cautious attempt to link the rules shaping interaction patterns to the performance of food quality governance, we focus on two criteria that are critical to the long-term performance of GI governance: Coordination of interests and adaptability.

Our first criterion for governance performance is the coordination of interests. Blomquist (2009, p. 115) summarises the major themes of polycentricity research, pointing to limited information processing capabilities of individuals; the existence of multiple goals, and the recognition of the diversity of human interests and values associated with most complex resource systems. This relates to the "key question ... [on] who is responsible for the process of developing, implementing and controlling standards and who decides which standards are helpful and necessary?" (Vogl et al., 2005, p. 17). Blurred responsibility and accountability are two main problems of governance approaches involving multiple private, public, and voluntary sector actors (Stoker, 2018). More and especially more heterogeneous actors involved are likely to result in higher transaction costs, i.e., more time spent on coordination, communication, conflict mitigation, etc. (E. Ostrom, 2010a). If the group is too small or too homogenous, it might be difficult to generate the knowledge and resources needed to effectively govern food quality. The complex interplay of diverse actors' resources, knowledge, interests, needs and worldviews is regulated by constitutional rules that apply to a particular place and time and determine who is involved in decision-making and who is excluded. Coordination among different actors is particularly important for the formulation of GI standards, the elaboration of which is based on knowledge, skills, practices, history, and culture of a community of people in a given geographical area (Allaire et al., 2011; Pick and Marie-Vivien, 2021). When experimenting with (new) food quality standards, such as those for GI, actors have access to certain knowledge, can anticipate and seek feedback on proposed modifications in food production and processing practices, and can learn from the experience of other producer organisations. Although redundancy can be time-consuming and is often criticised, it builds important capabilities and mitigates risks through diverse approaches (E. Ostrom, 2001).

Our second criterion of governance performance is adaptability. Subunits have considerable autonomy to experiment with diverse rules for using a given type of resource system and to respond differently to change and external shocks (E. Ostrom, 2001). How a polycentric organisation promotes or impedes innovation, learning, and adaption is a key question in polycentricity literature (E. Ostrom, 2010b). GI producers have to adapt their PS in response to evolving societal,

Table 1

Overview of illustrative country cases, affiliations and interviewees.

\begin{tabular}{|c|c|c|c|}
\hline & France PDO Reblochon (cheese) & Italy PDO Bitto (cheese) & $\begin{array}{l}\text { Austria PGI Marchfeldspargel } \\
\text { (asparagus) }\end{array}$ \\
\hline Documents (D) & $\begin{array}{l}\text { Regulation (EU) No } 1151 / 2012 \text { on quality schemes for agricultu } \\
\text { Original Product Specification } 1996^{1} \\
\text { Amendment application and approval } 2003^{1} \\
\text { Amendment application } 2014^{1} \\
\text { Amendment approval } 2015^{1} \\
\text { Current Product Specification } 2015^{2} \\
\text { INAO Guide du Demandeur (INAO, 2017) } \\
\text { Informal documents received by producer group (intermediate } \\
\text { versions of Product Specifications, summary of proposals in } \\
\text { national opposition procedure } 2011 \text { ) }\end{array}$ & $\begin{array}{l}\text { al products and foodstuffs } \\
\text { DOC Product Specification } 1995 \text { (Following } \\
\text { Italian Legislation) } \\
\text { PDO application and approval } 1996^{1} \\
\text { Original PDO Product Specification } 1996^{4} \\
\text { Amendment application } 2006^{1} \\
\text { Amendment approval } 2009^{1} \\
\text { Current product specification (after } \\
\text { amendment) } 2009^{4} \\
\text { Control plans related to the first and second } \\
\text { version of the product specification } \\
\text { Informal documents (blogs, newspaper articles, } \\
\text { comments related to the debate about the } \\
\text { product specification) }\end{array}$ & $\begin{array}{l}\text { Original Product Specification } 1996^{1} \\
\text { Amendment application and approval } \\
2002^{1} \\
\text { Current Product Specification } 2016^{3} \\
\text { Information sheet on Austrian GI } \\
\text { protection (Österreichisches Patentamt, } \\
\text { n.d.) }\end{array}$ \\
\hline $\begin{array}{c}\text { Interviews (I)/ } \\
\text { affiliations }\end{array}$ & $\begin{array}{l}4 \text { Reblochon milk producers (I-RP1, I-RP2, I-RP3, I-RP4) } \\
1 \text { Reblochon ripener (RR) } \\
1 \text { Reblochon producer group (I-RPG) } \\
1 \text { Local INAO (I-INAO-L) } \\
1 \text { INAO* Montreuil, Paris (I-INAO-P) } \\
1 \text { Local Chamber of Agriculture (I-CAR) }\end{array}$ & $\begin{array}{l}2 \text { Bitto producers (I-BP1, I-BP2) } \\
1 \text { Bitto ripener/marketing cooperative (I-BMC) } \\
2 \text { Representatives of the Bitto Consortium (I- } \\
\text { BC1, I-BC2) } \\
1 \text { Producer outside PDO (I-BOP) } \\
1 \text { Representative of association outside PDO (I- } \\
\text { BA1) } \\
1 \text { Local organisation of farmers (I-BF) } \\
1 \text { Local organisation of breeders (I-BB) } \\
1 \text { Local retailer (I-BR) } \\
1 \text { Researcher (I-BU) } \\
1 \text { Regional administration representative (I- } \\
\text { BADM) } \\
2 \text { Officers in national authorities (I-MIPAAF1, I- } \\
\text { MIPAAF2) }\end{array}$ & $\begin{array}{l}4 \text { Marchfeldspargel producers (I-MP1, I- } \\
\text { MP2, I-MP3, I-MP4) } \\
1 \text { Marchfeldspargel producer group (2 } \\
\text { producers: chairman and coordinator, I- } \\
\text { MP5) } \\
2 \text { Austrian Patent Office } \\
1 \text { Austrian federally organised Chamber } \\
\text { of Agriculture (I-CAR) } \\
1 \text { Service Association for GIs (I-SA) } \\
1 \text { Austrian Delicacy Region (I-DR) }\end{array}$ \\
\hline
\end{tabular}

Note: Interviewee identifications are used as references in the results section; Institut national de l'origine et de la qualité (INAO), Ministry of Agricultural, Food and Forestry Policies (MIPAAF), Protected Denomination of Origin (PDO), Protected Geographical Indication (PGI).

${ }^{1}$ Available on eAmbrosia (at the time of the research Door Database).

${ }^{2}$ Published in the Bulletin officiel du Ministère de l'agriculture, de l'agroalimentaire et de la forêt $n^{\circ}$ 19-2015; available at: https://info.agriculture.gouv.fr/gede i/site/bo-agri/document_administratif-cadf8434-ef21-4e02-b107-206a7c561c06/telechargement\#: :text=Le\%20\%C2\%AB\%20Reblochon\%20\%C2\%BB\%20ou\% 20\%C2\%AB\%20Reblochon,entre\%20450\%20et\%20550\%20grammes. (28.10.2021).

${ }^{3}$ Available at: https://www.patentamt.at/fileadmin/root_oepa/Dateien/Marken/Herkunftsangaben/Marchfeldspargel.pdf (28.10.2021).

${ }^{4}$ Available at Italian Ministry of Agriculture Website: www.politicheagricole.it. 
technological, market, environmental, and political conditions (Baritaux et al., 2016; Belletti et al., 2015; Bérard et al., 2016; Clark and Kerr, 2017; Edelmann et al., 2020; Marescotti et al., 2020). Intra-group factors, such as the number and heterogeneity of actors involved or relationships in the value chain, might also drive adaptations (Mancini and Consiglieri, 2016; Mariani et al., 2019; Millet and Casabianca, 2019).

\section{Methods}

\subsection{Comparative case study approach}

To understand the coordination of different interests and the adaptability of food quality standards, we investigate GI amendments at the $\mathrm{EU}$, national and local levels in a comparative multi-methods case study approach. Based on EU and national regulations on GI amendments, we first present the national amendment procedures in three EU Member States, which we then illustrate and compare using three cases of GI amendments, one in each country (Table 1).

The selection of case studies was operated at two levels: selection of i) countries within the EU; ii) a representative case study within each country. Regarding the countries, we tried to select illustrative case studies as diverse as possible (Seawright and Gerring, 2008), representing the variety of implementation of EU regulation 1151/2012 in terms of institutional context, associated practices and experience in the protection and governance of GIs. The selected countries were chosen based on the following criteria to explore the different forms of governance in the GI system at the European level: i) a gradient of centralisation in the national GI frameworks (ranging from regionally governed Italy to the federal state of Austria and to a centralised France); ii) the number of GI registrations and amendments, as a proxy for experience with GI governance (with Italy and France having very long experience and Austria having comparatively short experience). The following criteria were used for the selection of case studies in each country: i) product classes with the highest shares of amendments: cheese and fruit/vegetables (Quiñones-Ruiz et al., 2018); ii) within these product classes, one typical and illustrative case (Seawright and Gerring, 2008) per country for the diversity of implementation of rules and patterns of interaction and iii) interviewees' willingness to participate.

\subsection{Materials, data collection and analysis}

First, we analysed the GI laws and procedures applied by the selected Member States, as documented in guidelines and on official websites,

Table 2

Organisations formally involved in French GI amendment processes.

\begin{tabular}{|c|c|c|}
\hline Organisations & Composition/actors & Tasks \\
\hline $\begin{array}{l}\text { Producer group (Organisme de } \\
\text { Défense et } \\
\text { de Gestion) }\end{array}$ & $\begin{array}{l}\text { Producers and processors (each category of producers/processors has } \\
\text { to be represented) }\end{array}$ & $\begin{array}{l}\text { Represents GI interests } \\
\text { Elaborates and manages the PS } \\
\text { Elaborates a control plan, facilitates internal controls } \\
\text { Contributes to protection of the GI name/product/terroir } \\
\text { Facilitates product development, valorisation } \\
\text { Keeps registers for economic figures, market development }\end{array}$ \\
\hline $\begin{array}{l}\text { Local INAO offices (délégation } \\
\text { territoriale), } \\
8 \text { local INAO branches }\end{array}$ & INAO employees working in the local branches & $\begin{array}{l}\text { Local branches of INAO } \\
\text { Reports to INAO in Paris } \\
\text { Permanently accompanies, consults and exchanges with producer } \\
\text { groups concerning management of PS, controls, amendment } \\
\text { processes }\end{array}$ \\
\hline $\begin{array}{l}\text { INAO Paris - Montreuil-sous-Bois } \\
\text { (Head Office) }\end{array}$ & Administrative staff employed by INAO & $\begin{array}{l}\text { Reports to the Ministry of Agriculture } \\
\text { Manages implementation strategies for French GIs } \\
\text { Provides legal support for GI development } \\
\text { Promotes GI concepts in general } \\
\text { Responsible for international cooperation }\end{array}$ \\
\hline $\begin{array}{l}\text { INAO - Permanent } \\
\text { Board (representtatives of } \\
\text { National Committees) }\end{array}$ & $\begin{array}{l}\text { Includes representatives of the } 5 \text { National Committees, the Board of } \\
\text { Approvals and Controls, administration representatives nominated by } \\
\text { the Ministry of Agriculture }\end{array}$ & $\begin{array}{l}\text { Steering body of INAO } \\
\text { Provides strategic guidelines } \\
\text { Responsible for the budget }\end{array}$ \\
\hline $\begin{array}{l}\text { INAO - National Committees ( } 5 \text { for } \\
\text { various products/quality labels) }\end{array}$ & $\begin{array}{l}\text { Representatives of professionals (producers, processors, traders), } \\
\text { qualified persons (researchers, consumers), national administration } \\
\text { (Ministries of Agriculture and Economy; Finance; Environment) } \\
\text { Representatives nominated by the Ministry }\end{array}$ & $\begin{array}{l}\text { Reviews and approves applications for GI registration and } \\
\text { amendment } \\
\text { Decisions (made by anonymous voting) form a guiding opinion/ } \\
\text { philosophy for French GIs }\end{array}$ \\
\hline $\begin{array}{l}\text { Enquiry } \\
\text { Commission }\end{array}$ & $\begin{array}{l}\text { Consists of members of the National Committees (who have no } \\
\text { conflict of interest) } \\
\text { Nominated by the permanent board for each amendment to the } \\
\text { National Committee that takes the final decision on the nomination }\end{array}$ & $\begin{array}{l}\text { Exchanges with producer group, local INAO offices, or other } \\
\text { persons who may be of interest for the amendment } \\
\text { Prepares a report (including PS, control plan, expert report) on } \\
\text { amendment impacts and makes recommendations to the National } \\
\text { Committee that makes the final decision }\end{array}$ \\
\hline $\begin{array}{l}\text { Expert } \\
\text { Commission }\end{array}$ & $\begin{array}{l}\text { Nominated by National Committees if geographical area is amended } \\
\text { Consists of experts for the geographical area in question }\end{array}$ & $\begin{array}{l}\text { Defines natural and human criteria for delineating or amending a } \\
\text { geographical area } \\
\text { Studies written documents, statistics, personal knowledge, } \\
\text { exchange with (local) stakeholders } \\
\text { Elaborates a tentative map of the future geographical area }\end{array}$ \\
\hline $\begin{array}{l}\text { INAO - Board of Approvals } \\
\text { and Controls }\end{array}$ & $\begin{array}{l}\text { Representatives of control bodies, qualified persons, Ministries of } \\
\text { Agriculture and Economy, FranceAgriMer } \\
\text { Representatives nominated by the Ministry of Agriculture }\end{array}$ & Approves control structures \\
\hline Ministry of Agriculture & $\begin{array}{l}\text { Ministry officials who represent the } \\
\text { Ministry of Agriculture within the } \\
\text { National Committees }\end{array}$ & $\begin{array}{l}\text { Intermediary between INAO and the European Commission } \\
\text { Any decision taken by the National Committees has to be validated } \\
\text { by the Minister before being forwarded to the European } \\
\text { Commission } \\
\text { Responsible for transmitting the Single Documents and the } \\
\text { amendment application to the European Commission } \\
\text { Publishes the (amended) PS in the Official Bulletin of the Ministry } \\
\text { of Agriculture }\end{array}$ \\
\hline
\end{tabular}

Note: Institut national de l'origine et de la qualité (INAO); L'Établissement national des produits de l'agriculture et de la mer (FranceAgriMer).

Source: Own illustration based on documents and interviews as listed in Table 1. 
Table 3

Organisations formally involved in Italian GI amendment processes.

\begin{tabular}{|c|c|c|}
\hline Organisations & Composition/actors & Tasks \\
\hline MIPAAF & $\begin{array}{l}\text { Officials of the Directorate General for the Promotion of Agri-Food } \\
\text { Quality and Horse Racing, Office "Certified quality and protection } \\
\text { of geographical indications for agricultural, agri-food and wine } \\
\text { products" }\end{array}$ & $\begin{array}{l}\text { Responsible for the implementation of the EU regulation on GIs (e.g., } \\
\text { registration of amendments); it employs some officials, competent for } \\
\text { the sector of the protected denominations }\end{array}$ \\
\hline $\begin{array}{l}\text { Consortium - Producers } \\
\text { organisation appointed by } \\
\text { MIPAAF (Consorzio di tutela) }\end{array}$ & $\begin{array}{l}\text { Producers and processors } \\
\text { Ministry appoints consortia that are representative of producers } \\
\text { according to a set of criteria established in the Ministerial Decree } \\
\text { April 12, 2000, and subsequent amendments. }\end{array}$ & $\begin{array}{l}\text { Drafts the amendment request and related documents. The application } \\
\text { file must contain a note on the amendment request, a confirmation of } \\
\text { its compliance with the representativeness rules, the new PS with the } \\
\text { proposed amendments, the Single Document, and, if applicable, a } \\
\text { technical-scientific report. } \\
\text { Approves the request for PS amendment (qualified majority) } \\
\text { Submits the amendment request to MIPAAF and the competent } \\
\text { regional administration } \\
\text { Represents GI interests during the amendment process }\end{array}$ \\
\hline $\begin{array}{l}\text { Producer group (if there is no } \\
\text { Consortium appointed by } \\
\text { MIPAAF) }\end{array}$ & $\begin{array}{l}\text { Producers and processors } \\
\text { The application must be made by the enterprises entered in the GI } \\
\text { control system representing at least } 51 \% \text { of the certified production } \\
\text { of the last solar year (or production year) and at least } 30 \% \text { of the } \\
\text { number of enterprises included in the control system. In absence of } \\
\text { certified production, the amendment must be requested by two- } \\
\text { thirds of the producers registered with the control body. }\end{array}$ & Approves the request for PS amendment \\
\hline Regional administration & Depending on the internal organisation of each region & $\begin{array}{l}\text { Can interact with and consult applicants } \\
\text { Submits comments to MIPAAF within } 90 \text { days of application } \\
\text { submission } \\
\text { Organizes, together with MIPAAF and the producer group, a public } \\
\text { meeting in the delimited GI area }\end{array}$ \\
\hline
\end{tabular}

Note: Ministry of Agricultural, Food and Forestry Policies (MIPAAF).

Source: Own illustration based on documents and interviews as listed in Table 1.

Table 4

Organisations formally involved in the Austrian GI amendment process.

\begin{tabular}{|c|c|c|}
\hline Organisations & Composition/actors & Tasks \\
\hline $\begin{array}{l}\text { Producer groups (associations, } \\
\text { Vereine) }\end{array}$ & Mainly producers and processors & $\begin{array}{l}\text { Ensure/manage quality and reputation of the } \\
\text { GI product } \\
\text { Act legally compliant } \\
\text { Perform activities to promote and valorise the } \\
\text { GI product }\end{array}$ \\
\hline $\begin{array}{l}\text { Austrian } \\
\text { Patent Office }\end{array}$ & Employees of the Austrian Patent Office & $\begin{array}{l}\text { Responsible authority for GI registrations and } \\
\text { amendments at national level } \\
\text { Proves application documents (legal } \\
\text { conformity) } \\
\text { Rejects or approves applications at national } \\
\text { level } \\
\text { Provides legal support and advice to producer } \\
\text { group during the registration/amendment } \\
\text { process }\end{array}$ \\
\hline $\begin{array}{l}\text { Service Association for Geographical Indications } \\
\text { (Serviceverein für geschützte Herkunftsbezeichnungen für } \\
\text { Lebensmittel, } \\
\text { SVGH) }\end{array}$ & $\begin{array}{l}\text { Led by executive board } \\
16 \text { full members (including all Austrian producer groups) } \\
7 \text { associate members (including the Austrian Chamber of } \\
\text { Agriculture, the Chambers of Agriculture of Vienna, Lower } \\
\text { Austria, Styria and Carinthia) }\end{array}$ & $\begin{array}{l}\text { Supports producers } \\
\text { Proposes further products for GI protection } \\
\text { Raises consumer awareness for GI products } \\
\text { Information and advisory platform } \\
\text { Assists with GI registration and amendment } \\
\text { or with other legal matters }\end{array}$ \\
\hline $\begin{array}{l}\text { Advisory Board for Geographical Indications (Beirat für } \\
\text { geschützte Herkunftsbezeichnungen) }\end{array}$ & $\begin{array}{l}\text { Representatives of the: } \\
\text { Ministry of Agriculture, Regions and Tourism } \\
\text { Ministry of Social Affairs, Health, Care and Consumer Protection } \\
\text { Ministry of Digital and Economic Affairs } \\
\text { Austrian Patent Office }\end{array}$ & $\begin{array}{l}\text { Facilitates the exchange of information } \\
\text { Consultation on legal interpretation } \\
\text { Elaborates national regulations to EU legal } \\
\text { acts }\end{array}$ \\
\hline
\end{tabular}

Source: Own illustration based on documents and interviews as listed in Table 1.

and for each of the cases, the official application and approval documents for the amendments. Between July and November 2017, and for selective follow-up clarifications in 2018 and 2019, we conducted semistructured interviews with producers, processors, authorities, and experts to grasp the interaction of actors within and between different organisations (Table 1 ).

We used a purposeful snowball sampling to recruit key informants holding insights from direct involvement in the amendment process (Creswell and Plano Clark, 2011) until information saturation (Rubin and Rubin, 2011). The diversity of groups and organisations involved in the national amendment processes resulted in a diverging number of interviewees (see Table 1). A common interview guideline supported comparable data collection in the French, German, and Italian language interviews. The interview guideline included questions about the actors and organisation involved in the amendment process, actors' motivations, formal procedures, and informal interaction patterns, the development of the national GI system, the evolution of individual GI cases and their PS - including a chronological and visual representation of the amendment process. Interviews lasted between 30 and $180 \mathrm{~min}$ and were recorded and transcribed.

A computer-assisted qualitative content data analysis was conducted in English following Gläser and Laudel (2010). To study the institutional 
Table 5

Three distinct national GI approaches.

\begin{tabular}{|c|c|c|c|}
\hline Levels & $\begin{array}{l}\text { France: } \\
\text { Territorial heritage approach }\end{array}$ & $\begin{array}{l}\text { Italy: } \\
\text { Rural development approach }\end{array}$ & $\begin{array}{l}\text { Austria: } \\
\text { Intellectual property rights approach }\end{array}$ \\
\hline $\begin{array}{c}\text { Natio- } \\
\text { nal }\end{array}$ & $\begin{array}{l}\text { Several National Committees/Boards, Commissions of } \\
\text { INAO*, all levels of regulations including operational } \\
\text { rules affecting food quality/identity; Expert } \\
\text { Commission* with scientists in case of delimitation } \\
\text { changes }\end{array}$ & $\begin{array}{l}\text { Ministry* (focus on constitutional and collective choice } \\
\text { rules) }\end{array}$ & $\begin{array}{l}\text { Patent Office* (focus on constitutional and } \\
\text { collective choice rules); since 2016: Service } \\
\text { Association, Advisory Board }\end{array}$ \\
\hline $\begin{array}{c}\text { Regio- } \\
\text { nal }\end{array}$ & Not relevant & $\begin{array}{l}\text { Regional authorities* (collective choice rules), farmer } \\
\text { organisations, other stakeholder groups, municipalities, } \\
\text { scientists, others (operational rules); public hearing* in } \\
\text { case of delimitation changes or if the amendment is not } \\
\text { presented by an appointed Consortium }\end{array}$ & Not relevant \\
\hline Local & $\begin{array}{l}\text { Producer group* interacts with local INAO office and } \\
\text { higher-level organisations*, horizontal links* with other } \\
\text { producer groups in the same and other regions via INAO } \\
\text { processes; collective choice rules in statutes of the } \\
\text { Organisme de Défense et de Gestion shaping decision- } \\
\text { making among producers on PS and practices }\end{array}$ & $\begin{array}{l}\text { Producer group* - formal voting rules defined in national } \\
\text { GI legislation, collective choice rules in consortium } \\
\text { statutes shaping decision-making among producers and } \\
\text { on PS and practices }\end{array}$ & $\begin{array}{l}\text { Producer group*; collective choice rules are } \\
\text { defined in the statutes of the association shaping } \\
\text { decision-making among producers and on PS } \\
\text { and practices }\end{array}$ \\
\hline
\end{tabular}

Note: *required by law; Institut national de l'origine et de la qualité (INAO).

Source: own illustration based on documents and interviews as listed in Table 1

framework for amendment procedures, we analysed the levels of rules, the actors involved, their interests and positions, their interaction patterns, and the respective outcomes (changes in PS and practices). The levels of rules (see Section 2) included both formal GI rules (modifications of food quality standards codified in the PS) and informal practices that were adopted complementary or - possibly - in contradiction to the formal rules. We used the same deductive and inductive (from transcripts) categories in all cases.

\section{Results}

The results section first presents the constitutional and collective choice rules for each country, i.e., the rules that govern the interactions of the actors. It then shows, how these interactions affect specific amendment processes, focusing on evolving quality standards codified in the PS and actual production practices.

\subsection{Governance of GI amendments in France}

\subsubsection{Constitutional and collective choice rules}

The constitutional rules define which actors and organisations are involved in the amendment processes of French GIs (Table 2). The collective choice rules define their interaction patterns, as shown in Fig. 2.

The central authority is the INAO (Institut national de l'origine et de la qualité), which operates through local INAO branches responsible for of preparing documents, advising and accompanying local actors, and through the national head office, which provides legal support and negotiates with the French Ministry of Agriculture. Decisions are made by the National Committee - a body that deals with applications and amendments. This National Committee is a public-private body with representatives of GI producer groups responsible for safeguarding the reputation of the GI.

When the producer group decides to amend its PS and discusses the possible amendment, it needs to interact with the local INAO (1; see continuous arrow number 1 in Fig. 2) to prepare the amendment application. The local INAO asks the producer groups to reflect on their amendment (concerning motivations, objectives, consequences, economic impact, feasibility for all, preservation of the spirit/philosophy) in order to prepare for the argumentation with the Enquiry Commission. This first phase can be lengthy and complicated (I-INAO-L), as the producer group must clearly formulate the amendment (according to the previous text) and justify it. The producer group transmits the application to the local INAO, which analyses the formal requirements as well as technical, legal, and economic aspects of the amendment (2). The local INAO then forwards the application to the National Committee, which reviews the application (3) and decides whether the application is rejected, needs further elaboration, or if it can be submitted for consideration. If the application is approved, an Enquiry Commission is officially nominated and the producer group is advised to initiate a preinformation for the public in the local press (4) so that potential opponents are informed in a timely manner to set up a control plan (A).

An Enquiry Commission consists of members of the National Committee who do not have conflicts of interests with the GI product in question (5). The Enquiry Commission works with local INAO branches, reviews the amendment application, and exchanges views with producer groups, experts, or other relevant actors. Then, the Enquiry Commission makes a recommendation to the National Committee (6). If the amendment concerns the geographical area, an expert commission is nominated by the National Committee, consisting of multidisciplinary external experts. Based on personal experience, documents, and field research, the expert commission develops criteria for the delimitation of the geographical area and reports back to the Enquiry Commission. Based on these reports, the National Committee decides whether the amendment application has to be rejected, requires further investigation or elaboration, is approved directly (in case of minor amendments), or the national opposition procedure is initiated. In the latter case, individuals or legal entities have two months to object to the amendment (7). The producer group has to prepare answers to each objection, and the National Committee reviews the oppositions and the corresponding responses (8) and decides whether to approve the amendment (9). According to the interviewees, the National Committee is more willing to accept an amendment if it strengthens the link to the territory (I-INAOL).

After the national opposition period, the INAO approves the control plan, rejects it, or asks the producer group to modify it (B). If the amendment is approved, the new PS is published in the Official Bulletin of the Ministry (10). The Ministry also transmits the amendment application to the European Commission (11). While in some cases, there are long delays before the amendment is approved at the EU level, it can be valid immediately at the national level if the producer group requests it (I-INAO-L). In addition, the dashed arrows (Fig. 2) indicate additional, not formally regulated exchange that was reported by the interviewees of the analysed cheese case. 


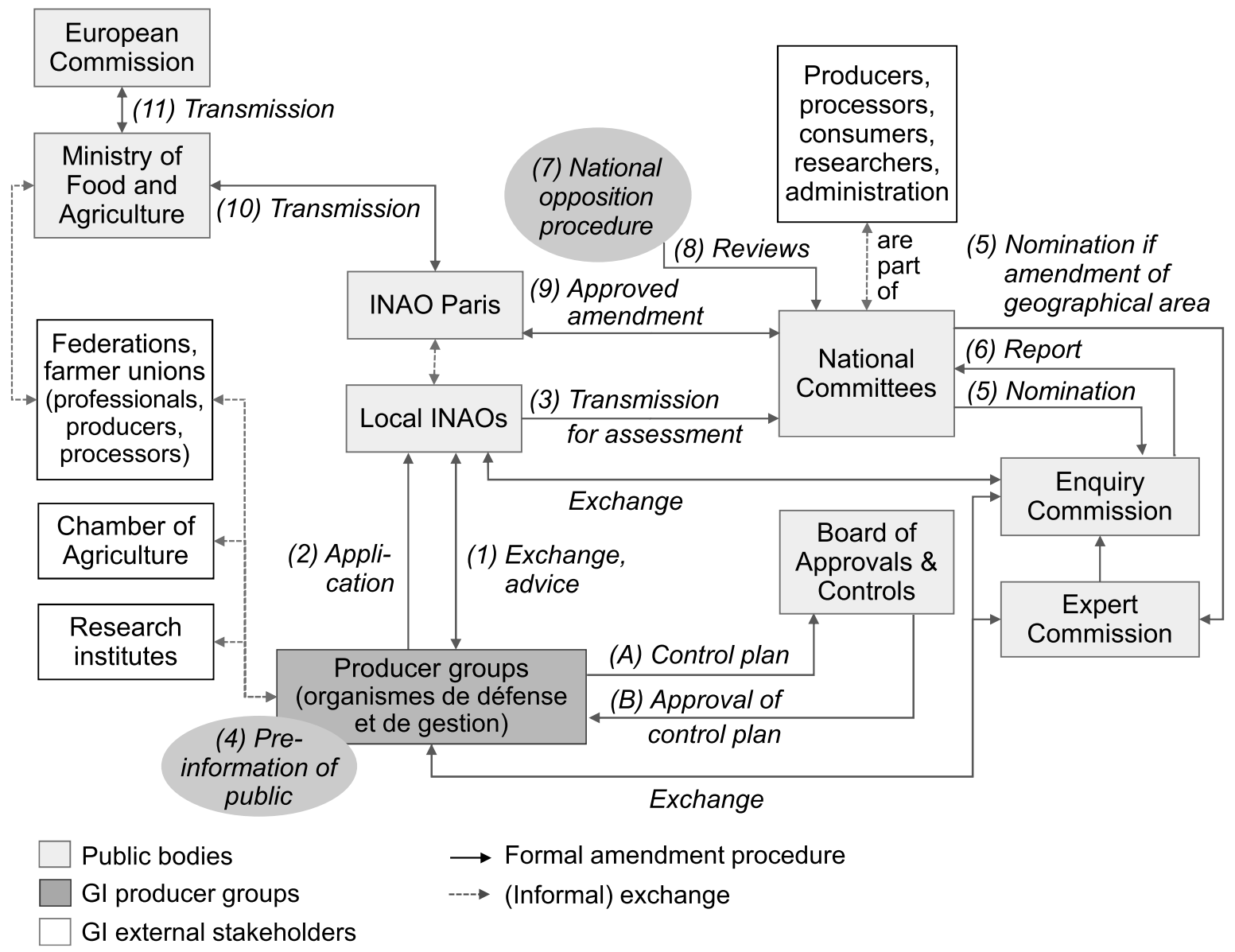

Fig. 2. Interaction patterns in France (own illustration based on documents and interviews as listed in Table 1).

\subsubsection{The Reblochon case study and the adaptation of operational rules}

We turn now to our illustrative case of Reblochon and selected modifications negotiated as part of the amendment published in 2012. This cheese is made from raw and cow's whole milk by about 700 producers and processors in Haute-Savoie and the Val d'Arly in Savoie, a mountain area with diverging production conditions for farms at higher and lower altitudes. Most agricultural land is used for grazing. According to the PS, $90 \%$ of the grassland is used as permanent grassland, including characteristic mountain pastures. An increase in urbanisation and industrial activities puts pressure on the agricultural area (I-RPG).

The GI was registered at national level in 1958 and in the EU in 1996. It is managed by the Syndicat du Reblochon and its 24 members, i.e., six for each of the four stakeholder groups involved in cheese production: on-farm cheese processors (fermiers), milk producers (delivering milk to dairies but do not produce cheese themselves), cheese manufacturers and cheese refiners (aging the cheese). Six persons (and one intern) work in the administrative council, two in the office, and other groups elaborate specific topic (e.g., communication, evaluations of organoleptic characteristics, supply management). The tasks of the Syndicat are PS management and control, lobbying at national and regional levels, support to producers on technical or sanitary issues, research/market analyses and the implementation of the marketing strategy (I-RPG). To amend the PS, producers must provide the assigned Enquiry
Commission with substantiated arguments for each of the modification proposed in the amendment application. The Syndicat commissions studies or requests expertise from the Chamber of Agriculture to argue for a requested modification (I-RPG). French governance structures require producer groups to carefully consider their amendments, and consult experts or bodies that are not part of the producer group itself.

The Reblochon PS was amended at the national level in 1999 and 2012 (the content corresponds to the amendment at EU level in 2003 and 2015). Each of these amendments brought several modifications that had a strong impact on collective choice and operational rules. For example, the current PS determines that Reblochon can only be produced by milk from three local cow breeds. During the discussions on the 2012 amendment application, Syndicat members agreed to introduce two non-local additional breeds due to the interest of some farmers. A few farms still used these two breeds as they correspond to a kind of intensification of milk production. However, as they are no local breeds, their inclusion in a positive list of recognised breeds had to be confirmed. However, the National Committee decided that the GI Reblochon could not increase the number of breeds (only reduce it and focus on the very local ones). The decision was made to preserve the traditions and identity of the GI, which is a fundamental criterion in the decision-making processes of the National Committee (I-RPG, I-RP1, IRP2). As a result of the collective choice, no additional breeds were 
included in the 2012 amendment.

Another example of a dispute on operational rules concerns milking robots. In the first draft amendment from 2011, the producer group wanted to ban milking robots completely. However, some producers (especially those with more cows) wanted to allow them without restriction and objected in the national opposition procedure (I-RPG, IRP1, I-RP2). One of the challenges of using a milking robot is that if cows can be milked all day, they spend less time on the pasture and require more supplemental fodder, and the production system will intensify (with assumed modifications in milk composition and its ability to be processed into the typical cheese) (I-RP4). Following this debate within the producer group, a compromise was reached that allows the use of milking robots with conditions: Producers may only use them twice a day for $4 \mathrm{~h}$ each time, with 8 -h break between milkings. The compromise on these operational rules was accepted by the National Committee and the Administrative Council of the Syndicat and was approved in the 2012 amendment. Nevertheless, the milking robot still was a controversial topic at the time of fieldwork (I-RPG, I-RP1, I-RP2).

The cases - particularly the failure of producers to extend the breed list, and the negotiation of interests in the national opposition procedure concerning milking robots - illustrate INAO's role in protecting the identity of the product.

\subsection{Governance of GI amendments in Italy}

\subsubsection{Constitutional and collective choice rules}

The organisations and actors involved in Italian GI amendment processes are described in Table 3, and their interaction pattern are shown in Fig. 3.
The Ministry of Agricultural Food and Forestry Policies is responsible for the national phase. The Ministry's Decree of October 14, 2013 regulates the advisory roles of regional authorities, the bottom-up approach, and the representativeness quorum of applicants. Constitutional rules stipulate that only producers using the GI are entitled to initiate an amendment process, while in the absence of certified production, the amendment must be requested by producers registered with the control body. Applicants have to comply with the representative quorum as defined in the ministerial decree (if organised as a consortium) or representation criteria based on both certified production and the number of producers involved (see Table 3 ).

Fig. 3 illustrates that producers must address their application to the regional administration responsible for the delimited area (1). The regional administration links the local level of GI production with the Ministry and plays both a formal and an informal role in the process. Very often, an office of the regional administration specifically responsible for GIs advises producers on the changes they are requesting. The regional administration can ask for a meeting with the Ministry to evaluate the amendment dossier (within 60 days from the application) (2), which allows for better coordination between the national and regional levels and strengthens the advisory role of the regions.

After this meeting, the regional administration must submit its opinion to the Ministry (within 90 days from the application) (3). The Ministry reviews the application and may ask the applicants for clarification or additional information. If the Ministry's final decision is to approve the amendment, and only if the amendment concerns the delineation of the production area or if it is not submitted by a designated consortium, a public meeting is organised within the delimited GI area (4). In this way, the Ministry can verify the compliance of the

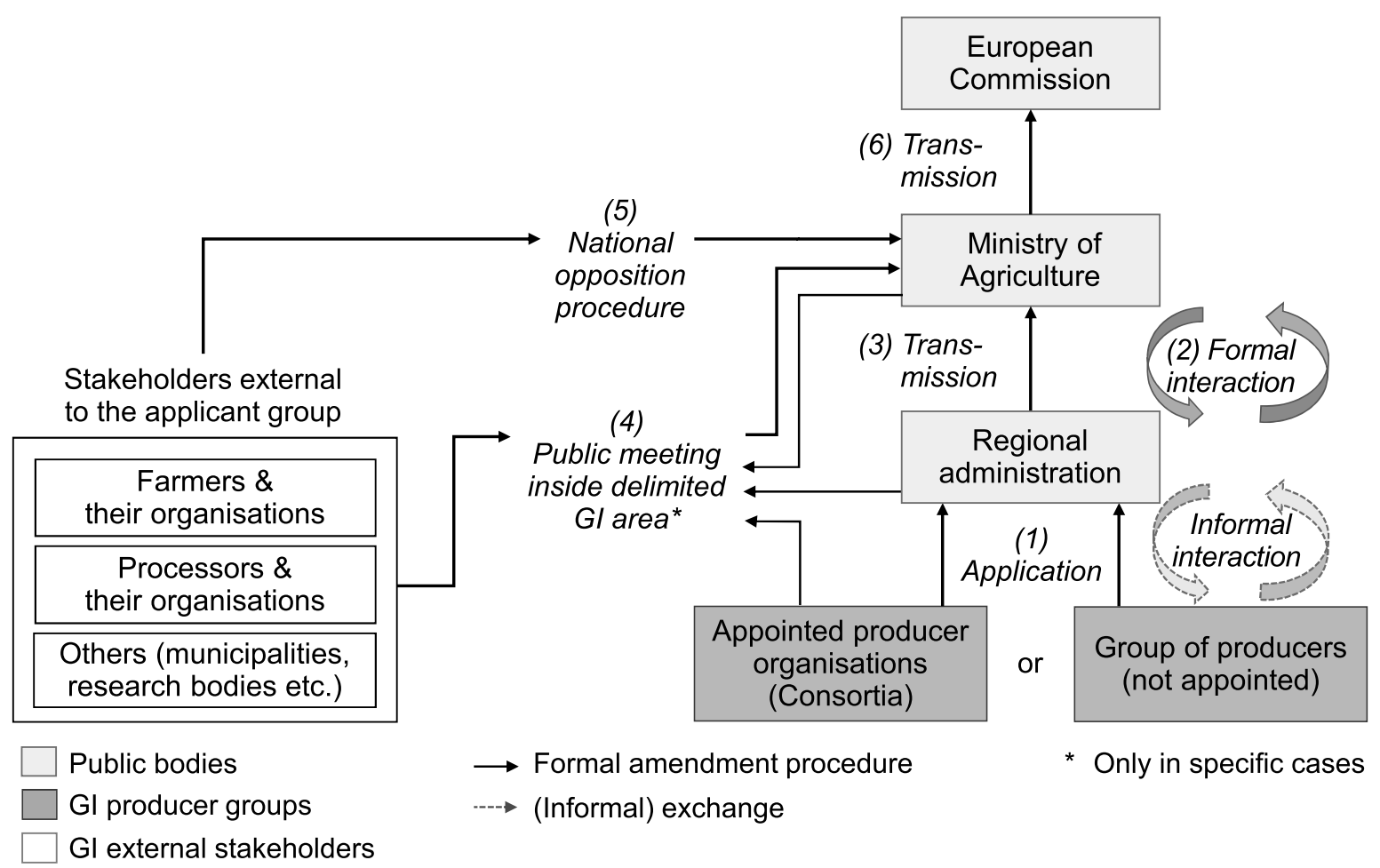

Fig. 3. Interaction patterns in Italy (own illustration based on documents and interviews as listed in Table 1). 
amendments to fair and consistent production methods and allows the opponents to express their views.

At the end of the process, the final version of the amended PS is published in the Italian Official Journal, giving the opportunity for oppositions (5). In case of an opposition, the Ministry makes the final decision in agreement with the regional administration. If the decision is positive, the amended PS is published in the Italian Official Journal and forwarded to the EU Commission (6). At the ministry level, the process is run by officials without formal involvement of professionals or experts. Some regions (e.g., Emilia Romagna, Regional Resolution 1682/2014) have enacted specific laws to regulate the regional phase of the process and to define specific internal competences for elaborating their opinion on the GI amendment application. These regional procedures allow all interested party to comment on the proposed PS amendment from the beginning of the process and in a less formal way than through formal opposition.

\subsubsection{The Bitto case study and the adaptation of operational rules}

As an illustrative example for Italy, we analysed the cheese Bitto and more specifically selected modifications negotiated for the amendment approved in 2009. This Protected Designation of Origin (PDO) is a seasoned cheese (at least 70 days) made from raw cow's whole milk in Valtellina, an alpine valley near the Swiss border. Bitto was registered as Denominazione di origine controllata (DOC) according to Italian law in 1995 and as a PDO under EU law in 1996. The main motivation for the PDO registration was the valorisation and economic development of the Valtellina valley and the increasing production of Bitto cheese, which went beyond the traditional Bitto production area (I-BU). A basic operational rule, according to the PDO specification, is that Bitto PDO can only be produced from 1 June to 30 September. In 1996, producers formed the "Consorzio per la tutela dei formaggi Valtellina Casera e Bitto", which associates producers and ripeners of two PDOs, Bitto and Casera.

The PS needed for registration was broadly approved by the local farmer association, breeder association, DOC association, the Chamber of Commerce, and the municipalities, although a minority of producers from one valley (Val Gerola), who wanted to maintain traditional practices, expressed doubts about extending the production area beyond the delimitation originally defined for the DOC. However, traditional producers stayed in the Bitto PDO consortium and labelled their cheese as PDO.

After the recognition in 1996, producers and ripeners suggested reflection on some operational rules due to the technological and production development. In particular, there was a discussion about allowing cows to be fed a limited amount of dry fodder in addition to grazing on alpine pastures and using native starter cultures to improve the cheese-making process, reduce the incidence of defects, and to ensure the safety of the product (I-BMC1). The consortium has also conducted research that has shown that dry fodder and local starter cultures have no impact on the quality characteristics of Bitto. The local cooperative has gained experience with starter cultures from other cheeses (I-BC2), and local dairies have encouraged producers to use them because they diminish irregularities, thereby reducing noncompliance with PS regulations and increasing the proportion of the labelled product (I-BU1, I-BR).

The regional administration of Lombardy supported these considerations within the consortium. In accordance with the principle of representativeness of the Italian regulatory framework, the majority of the Consortium members decided to initiated the amendment process. The amendment application was submitted to the national authorities in
2006. The modifications mainly concerned the possibility of supplementing the diet of cows on pasture with a maximum of $3 \mathrm{~kg}$ of dry fodder per day and the possibility of using native starter cultures. Fearing impacts on traditional taste and flavour by dry fodder and bacteria (I-BOP), traditional producers withdrew from the PDO and formed the Bitto Storico Association of Producers (I-BMC, I-BU1) when the amendment was submitted to the Ministry in 2006.

After the amendment was formally submitted, the national process phase started. The consortium, large dairies, local breeder and farmer organisations, and the local Chamber of Commerce promoted the new $\mathrm{PS}$ rules (I-BU). The regional administration of Lombardy supported the amendment process and played an important role in mediating the conflict. It promoted numerous meetings between the consortium, government institutions, and Bitto Storico producers (I-BADM) during a three-year national phase (2006-2009). An important role in coordinating interests was played by the region of Lombardy, whose mediation resulted in an agreement on the extension of the PDO area, even though "Bitto Storico" producers continued to oppose to the amendment during the national phase, also using the press and mass communication tools.

When the Bitto amendment was approved in 2009, the members of the Bitto Storico Association were sanctioned for using the name Bitto and turned into a new competing producer association named "Storico Ribelle" (Historical Rebel). They even took their position to European authorities, but the claim did not comply with formal regulations and was rejected (I-BU). The Slow Food Association supported the Storico Ribelle producers and helped them to gain reputation, which also let to higher prices compared to the Bitto PDO (I-BA1, I-BR). To reconcile the different interests, the regional administration continued to support meetings between representatives of the consortium, government institutions, and Storico Ribelle producers. The outcome of these discussions was that producers using stricter practices were allowed to add the name of their mountain pasture on the label. This differentiation in terms of operational rules helped them to obtain a higher price to compensate for additional costs and risks (I-BADM), considering that even after the PDO registration producers used the name of the alpine pasture rather than the Bitto PDO (I-BOP, I-BP1). The Bitto case shows that regional administration plays a (tentative) mediating role amid conflicting interests at the regional level, where different actors can hold local debates and more easily find ways to express their viewpoints. The national level often takes for granted what the regional administration transmits for final approval.

\subsection{Governance of GI amendments in Austria}

\subsubsection{Constitutional and collective choice rules}

The organisations and actors involved in of Austrian GI amendment processes are described in Table 4, and their interaction patterns are depicted in Fig. 4.

The continuous arrows in Fig. 4 show the actor interactions of the formal GI amendment process in Austria, which starts with internal discussions in the producer group and their exchange with the Austrian Patent Office (1). When the internal discussions have led to a final draft of an amendment application, it is sent to the Patent Office (2). The Patent Office reviews the amendment application, and at the same time, the Ministry of Social Affairs, Health, Care and Consumer Protection proves the application for issues relevant to control. Other stakeholders may also be asked for their expertise as part of the process. Once the application is approved, it is published on the website of the Patent Office and oppositions can be filed within three months (3). These are examined, the national approval is published on the website, and the 


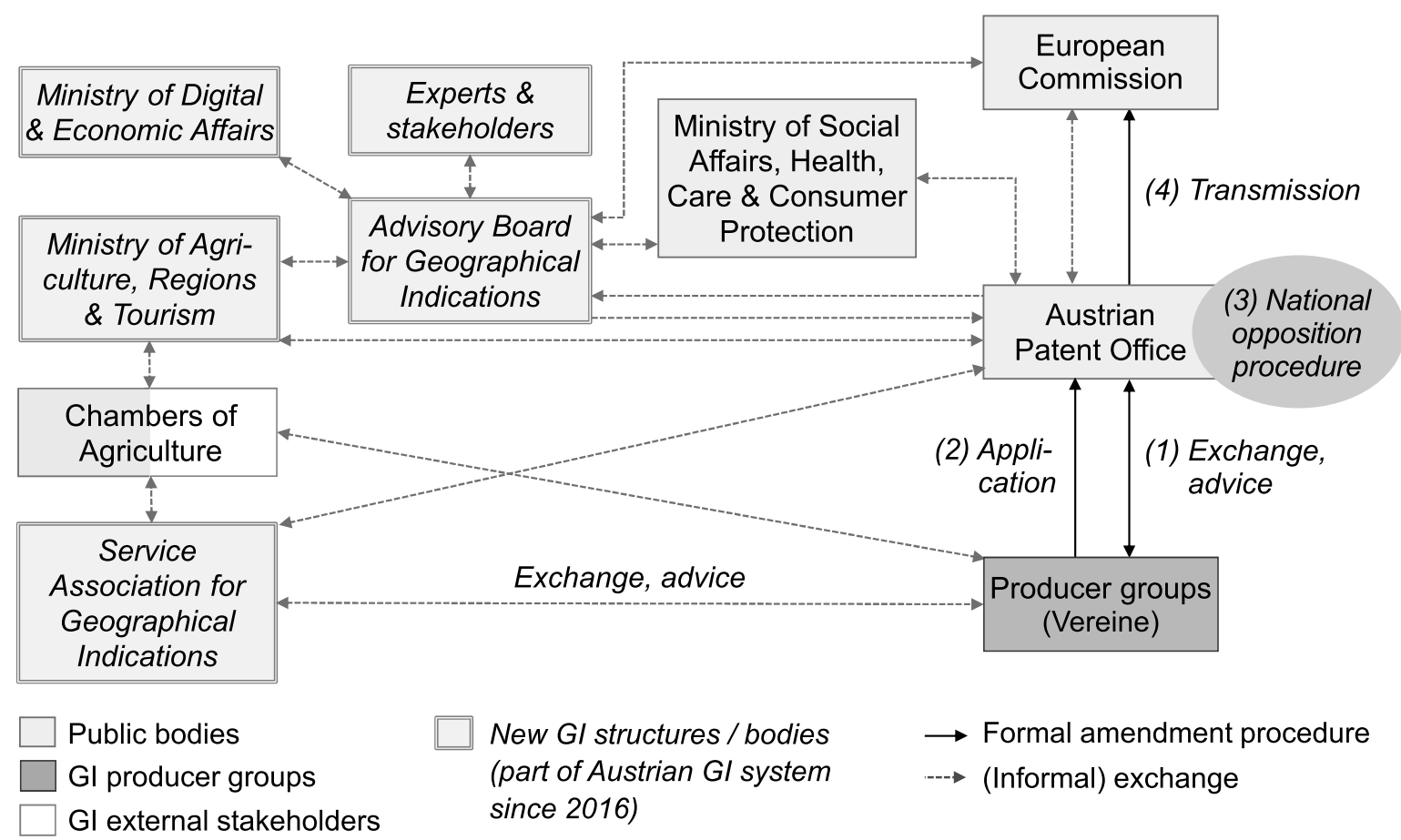

Fig. 4. Interaction patterns in Austria (own illustration based on documents and interviews as listed in Table 1).

Patent Office forwards the amendment application to the European Commission (4).

In 2016, i.e., after the amendment of our illustrative GI case was already approved, two new Austrian GI bodies were created: Service Association and the Advisory Board. Although amendments can still be made without involving the Service Association, the Patent Office strongly recommends consulting it before filing the application. Since this consultation is not compulsory, the formal amendment procedure remains the same, as illustrated by the continuous arrows in Fig. 4.

4.3.2. The marchfeldspargel case study and the adaptation of operational rules

We analysed the Marchfeldspargel amendment as illustrative example. The amendment was approved in 2002. The asparagus is cultivated in the region of Marchfeld in the province of Lower Austria. The producer group was founded in the 1980s as the "Bund der Marchfelder Spargelgüter" and included asparagus producers with common marketing goals (I-MP2, I-MP3). The producers sell the asparagus either directly at the farm or in supermarkets and gastronomy (I-MP1, I-MP2, I-MP3). They registered the PGI in 1996. Already one year after registration, producers started discussing an amendment at their meetings held several times a year (I-MP1, I-MP2). The original PS addressed operational rules by determining the length of the asparagus stalks at a maximum of $21 \mathrm{~cm}$ to distinguish them from comparable longer products (I-MP1, I-MP4, I-MP5). Shorter stalks were supposed to be more tender and thus of higher quality (I-MP2, I-MP5). However, as producers shortened the stalks, they also lost revenue due to a reduction of weight (I-MP1, I-MP2, I-MP4, I-MP5). Internal discussions about stalk length lasted a year and resulted in increasing the maximum length to $22 \mathrm{~cm}$. Nobody from outside the producer group participated in the debate on these operational rules. (I-MP1, I-MP2, I-MP3).

The original PS also included a list of 31 varieties that farmers can use to produce Marchfeldspargel. Due to international advances in plant breeding (I-MP1, I-MP2, I-MP3, I-MP5), new cultivation methods (IMP2) and variable soil and climatic conditions (I-MP1), debates about an extension of the variety list had started. While some producers wanted to eliminate any reference to varieties (to be able to choose any available variety), others feared that this flexibilization would lead to the cultivation of high-yielding varieties with a lower product quality (IMP2, I-MP3, I-MP4). The compromise on these operational rules (written down in the 2002 amendment) was to allow five additional varieties (I-MP3). The main drivers for the Marchfeldspargel amendment were the producers' wish for new varieties, and the price pressure on the asparagus market, which led to debates on quantity-quality trade-offs. The application was submitted to the Patent Office in 1998, and - after lengthy administrative processes, probably due to the fact that it was the first Austrian amendment application - was approved at EU level in 2002, without changes to the original application.

Several years after the amendment, the 17 farmers with farm sizes between 20 and more than 100 ha (I-MP3, I-MP4, I-MP5) were still discussing the varieties. In terms of operational rules, opinions ranged from continuously updating the list of varieties (I-MP5) to defining the characteristics of allowed varieties, enabling the use of new varieties meeting these characteristics without the need for repetitive PS amendments (I-MP5). Concerning the length of the asparagus stalks, some producers were still dissatisfied with the outcome and wanted to introduce ranges instead of fixed values or to reduce/extend the maximum length (I-MP2, I-MP3, I-MP4, I-MP5). Another farmer criticised the resulting rules as too vague and flexible, weakening existing quality standards (MP4).

Despite the multi-level governance process, the producer group decided autonomously on more flexible standards. Higher-level organisations focused on the formal aspects of the amendment (publication for the opposition period), and there was no technical exchange about the quality standards with actors outside the producer group.

\section{Comparative discussion of polycentric governance approaches}

Against the background progressing harmonisation and internationalisation of food quality standards (see Reinecke et al., 2012; Schouten and Bitzer, 2015; Spiekermann, 2011), we analysed who is actually responsible for changing the PS of French, Italian and Austrian GIs, through the lens of polycentric governance. The comparison benefited from an analytic distinction between constitutional and collective choice rules structuring the horizontal and vertical interactions 
of autonomous producer groups with other organisations on the one hand, and the food quality standards and production practices they collectively shape on the other hand (based on McGinnis, 2011). Due to the diversity of GI products and experiences in different EU Member States and producer groups, our three cases cannot represent the full spectrum, but rather illustrate three very different approaches to GI governance. Because the governance perspective is time- and place-specific (Stoker, 2018), our analysis cannot provide an all-encompassing explanation and answer to food quality governance in European GIs. The selection of two processed PDOs in France and Italy and an unprocessed PGI in Austria results in a less heterogeneous producer group in the Austrian case, which does not include processors. However, given the same constitutional and collective choice rules, we assume that the interaction patterns between the producer group and external organisations are independent of the product category and the type of protection. Despite these limitations, the comparative analysis confirms that the interaction patterns as regulated by the multilevel constitutional and collective choice rules affect decisions on - in our case - food quality and thus outcomes (see Morrison et al., 2019). It also shows how national contexts play out in diverging structures and functions of polycentric systems, confirming previous research on socio-ecological resource systems (Baldwin et al., 2018; Thiel and Moser, 2018; Villamayor-Tomas, 2018).

\subsection{Interaction patterns and coordination of diverse interests in food quality}

In all three cases, producer groups have defined and amended production rules on their own initiative, which is in line with the EU producer-led GI approach (Pick and Marie-Vivien, 2021). What differs from country to country is the GI vision, which resulted in distinct constitutional rules guiding the interactions of the different actors involved in the GI process in each country. Based on the interaction patterns, we distinguish between a territorial heritage approach in France (i.e., national authorities responsible for coordinating and regulating producer organisations), a rural development approach in Italy (i.e., a key role of regional authorities coordinating autonomous producer organisations) and an intellectual property rights approach in Austria, where the key-responsibility lies with autonomous decisions of individual producer groups (see Table 5). Consumer-citizens might not be aware of these diverse patterns of responsibility and accountability. This masking of responsibility is characteristic for governance approaches and contributes to the problems that citizens have in understanding and influencing the actions of their governments (Stoker, 2018).

The territorial heritage approach, which characterises the French model, is based on a vision inspired by the notion of common heritage and recognizes the patrimonial status of GI products. Following a technical and centralised approach, a wide range of competences (agronomic, zootechnical, technological, geographical, historical, etc.) are mobilised to guarantee the link between the GI product and its terroir. The National Committee is responsible for the level of GI ambition. It introduces new requirements meeting social expectations and respecting the product's identity rather than accepting ay regression or flexibilization of the standards. This is in line with the distinct approach of France identified for amendments in the fruit and vegetable sector (Marescotti et al., 2020). French GIs are governed by the INAO, a national organisation that - unlike national authorities in Italy or Austria also provides technical expertise on food quality based on the link between the product and the place of origin and open deliberation at national level through formal voting. The French constitutional and collective choice rules lead to a complex pattern of upward and downward pointing arrows between organisations at different levels and horizontal consultations between different producer groups. The National Committee plays an important role in assessing whether an amendment jeopardizes the link between the product and the territory (and thus its identity, tradition, and quality), and reviewing applications against a set of rules designed to preserve the core values of French GIs. These core values might be out of sight for local producer groups, which can be hassled by making decisions on rather short-term interests such as economic profitability and/or workload reduction (Marescotti et al., 2020). Based on the strong role of the INAO in shaping the operational rules for food quality standards, we could argue food quality reflects an understanding of GIs as national heritage. The French case illustrates the importance of the technical competences of national inter-professional committees to safeguard long-term and societal interests in identity and origin-based food quality as a national heritage. Nevertheless, Marie-Vivien et al. (2017) raised concern that the French GI system might lose its focus on the link to origin and thus its soul, due to changed governance processes, such as the privatization of controls in the EU GI system.

In Italy, the rural development approach is guided by the vision of GIs as a tool for the development of rural regions. GIs are mainly assigned to regional authorities in charge of rural development policies. As GIs are linked to localised agri-food systems, common goods of rural areas, and a rural development approach (Belletti et al., 2017), the constitutional rules ensure an interplay between the producer group and regional authorities to negotiate the diverse regional interests. Based on the principle of representativeness, the elaborated collective choice rules support transparent voting procedures within the producer group. The regional administration plays a coordinating and sometimes mediating role to reconcile the different interests that affect farm economics, but also environmental and social sustainability concerns of broader regional relevance, as represented in the Bitto case by the Slow Food Organisation on one side and the farmer association on the other side. The devolution of certain powers to regional administrations allows for a greater integration of GIs (and their amendments) into regional policies, which in each case may be more sensitive to agricultural, supply chain, market and/or environmental issues. In general, shifting an important part of decision-making to the regional level carries the risk or opportunity of greater stakeholder influence and the chance to integrate diverse approaches in different regions. The Ministry of Agriculture - as well as the Austrian Patent Office - usually does not intervene in operational rules and mainly grants the final approval after public and private interests were coordinated at the regional level.

In Austria, GIs are treated as an intellectual property right. They are managed at the national level by an organisation that has strong legal expertise on intellectual property rights but not much experience with origin products, neither from a technical point of view nor in terms of a possible integration into agricultural and rural development policies. Austrian producers have full autonomy and responsibility to define food quality. Referring to Newig and Koontz's (2014) definition of polycentric governance as a combination of multi-level governance and the direct involvement of non-state actors, we might even wonder whether the fully autonomous definition of food quality by Austrian producers has the necessary horizontal and vertical linkages to be considered an outcome of polycentric food governance. Due to the small and homogenous group, the asparagus producers were able to agree on the details of the amendment application comparatively quickly. Since they tended to perceived strict food quality standards as a competitive disadvantage, the flexibilization of rules was a logical outcome of the negotiations (confirming observations on other GI amendments by Clark and Kerr (2017) or Marescotti et al. (2020)). Despite the federally organised Austrian state, there is only one overarching organisation for GIs at the national level. The Austrian Patent Office focuses on formal aspects to ensure transparent registration and amendment processes. It is known for its legal expertise. Compared to the French INAO, the degree of specialisation on critical issues of agricultural production, food quality or territorial heritage is less specific. In 2016, additional advisory bodies were established for GI governance, but they do not play a mandatory role. It remains to be seen whether this optional exchange with other producer groups encourages the representation of broader societal 
interests such as the preservation of culinary traditions, typical breeds, or varieties. In terms of a more radical and socially inclusive change, the governance literature points to the limitations of governance approaches that strongly rely on autonomous self-governing actor networks (Stoker, 2018). Powerful governmental authorities, such as those in France, might be rather able to consider broader societal needs or more fundamental shifts in societal food quality expectations. Even if all members of GI producer groups are satisfied with the changes in the PS (which is usually not the case, as we have seen from the internal conflicts), an accountability problem can still arise because all groups are exclusive. They are driven by the self-interest of their members rather than a broader public interest (Stoker, 2018) or, in particular, those excluded from GI groups (such as producers outside the GI area, tourism sector representatives, nature conservation groups, consumer-citizens).

Among the countries studied, France shows the most complex polycentric governance, followed by Italy and Austria. Coordination by national or regional authorities in France and Italy supports the development of a common GI vision and encourages thinking and acting beyond the individual GI subsystem, avoiding undesirable side effects for consumer-citizens, national heritage, tourism, or gastronomy, and establishing mechanisms for effective coordination between individual GI groups - i.e., important roles of the government in shaping governance (Stoker, 2018). Austria has comparatively short experience in GI governance and a strong focus on producer responsibility for food quality standards, but a newly formed association should help to coordinate individual GI groups in the future.

Geographical delimitation touches on the central question of who is included and who is excluded from using and deciding on food quality (Pick and Marie-Vivien, 2021). This could be the reason why the two Mediterranean countries with long GI experience, defined specific constitutional and collective choice rules for changing the GI area. In both countries, the number of actors is extended to include additional expertise: In France, scientists provide criteria independent of the producer group; in Italy, broader expertise is drawn from an extended group of regional stakeholders going beyond the existing producer group and thus also including interests of other sectors or potential future GI users, i.e., producers who are not yet members of the producer group.

The Italian and French cases could be seen as ideal types of polycentric governance, as complex-adaptive systems due to the parallel and coordinated efforts of numerous groups experimenting with different rules (Andersson and E. Ostrom, 2008). Polycentric structures - i.e., autonomous, decentrally designed food standards that are negotiated in horizontal or vertical, cross-level governance settings - encourage interaction among multiple actors, which increases the time required for interaction, but might also raise coherence and promote learning that goes beyond local producers' experiences and interests that - according the EU producer-led approach - is central to the long-term adaption of food quality to changing (local) contexts.

\subsection{Adaptability of food quality}

Due to ongoing standardisation and internationalisation of food quality in prevailing agri-food systems, local autonomy and producer knowledge are being lost in food quality governance (see Reinecke et al., 2012; Schouten and Bitzer, 2015; Spiekermann, 2011; Vogl et al., 2005). GIs challenge the dominant agro-industrial systems through collective action by local producers who engage in bottom-up decision-making processes that lead to new hybrid governance mechanisms (Nizam and Tatari, in press). More or less autonomous local producer groups co-define food quality standards that are objectified in the so-called PS, which - due to its institutionalisation - can constrain local diversity and adaptability (Mariani et al., 2020). Our cases are not static 'museums of production' (Bowen and de Master, 2011; Gugerell et al., 2017), although they focus on heritage and traditional links with the territory. The comparative analysis shows that the national schemes analysed allow for context-specific, adaptive GI governance, but also that producers are under pressure to loosen food quality standards for reasons of short-term competitiveness (Marescotti et al., 2020; Millet and Casabianca, 2019). Comparing the French and the Austrian cases, both producer groups proposed to introduce new breed or varieties. However, French producers, after interaction with INAO, had to stick to their local breeds, which have been shown to contribute decisively to GI quality (Allaire et al., 2011; Bérard et al., 2016). The polycentric governance structures with strong horizontal and vertical feedback loops in France and Italy show that autonomous decision-making can be combined with information transfer and learning across scales and sectors, leading to innovative and robust adaptations (see Edelmann et al., 2020).

GI schemes could be positioned along the gradient between the Austrian system, which is most supportive of flexible adaptation, and the French system with great emphasis on the product identity and technical expert knowledge to strengthen the territorial link of the product. Both "lock-in" situations that impede local producers from innovatively adapting to change and weakening product identity, can jeopardize the long-term viability of the GI system (Edelmann et al., 2020). In contrast to the experiential knowledge of organic farmers that is lost through international organic standardisation (Vogl et al., 2005), GIs can support the sharing and preservation of tacit and traditional knowledge (Tashiro et al., 2019). Austria grants its producers the greatest autonomy and ensures that their - and only their - knowledge counts when GI standards are changed. In the older and more elaborated GI systems of France and Italy, scientific, technical, and administrative knowledge complementing the context-specific knowledge of local producers, also plays an important role. The INAO knowledge base, for example, includes diverse types of academic, technical, administrative, and experiential knowledge, all based on different epistemologies and learning methods (including knowledge sharing among producer groups with similar products).

Incorporating diverse types of knowledge and recognizing different epistemologies acknowledge the potential and limitations of human knowledge and understanding (Stoker, 2018), and human information processing capabilities and might reduce the risk of error-proneness (Blomquist, 2009, p. 115). Our cases show that vertical and horizontal linkages result in more robust amendments that conserve the identity and reputation of the food product, i.e., the common value protected with the GI. The involvement of numerous and heterogeneous actors, as in France or Italy, might be seen as an additional burden slowing down food quality adaptation due to high transaction costs (E. Ostrom, 2010a). However, France and Italy are among the countries with the highest shares of amended GIs (Quiñones-Ruiz et al., 2018). This might be evidence that the extra effort pays off in practice, and that clear roles and procedures can ensure effective interaction among heterogeneous actors and support broadly legitimated decisions within a reasonable timeframe. This additional debate might be particularly helpful when broad reflection is needed to distinguish between what can be changed and what needs to be safeguarded as historical tie or territorial link constituting the core identity of the product. In future studies, it would be interesting to cover all EU countries to identify diverging cases and different types of GI governance systems going beyond the three types described in this paper.

\section{Conclusion}

Based on a comparative analysis of constitutional, collective choice, and operational rules, we identified three distinct EU GI approaches: an intellectual property rights approach, where the power to define food quality is in the hands of producer groups acting autonomously; a rural development approach; and a territorial heritage approach, where producer groups are coordinated by regional or national authorities on the basis of a common GI vision. We analysed the diversity of polycentric structures, that link autonomous local producers with various actors and expertise for adaptive food quality governance. The perspective on polycentric governance enriches the debate on the adaptability of food 
quality standards, which is often guided by the dichotomy between harmonised, centrally defined standards and decentralised, autonomous producer innovation, or between state-driven top-down and producerled bottom-up approaches. From countries with long GI experience, we can learn, first the need for governance structures that allow for regional diversity and harness the full potential of the experiences of innovative producers who adapt their production to changing biophysical, socio-economic, and cultural contexts. Second, we are learning that producer aspirations need to be negotiated under a guiding umbrella, which ensures the consideration of long-term interests that may not be perceived by local producers. Broader integration of expertise and normative coordination across heterogeneous interests might prevent rapid changes from endangering the authenticity of the common cultural heritage. Time-consuming negotiation processes ensure that a critical number of actors consider changes in quality standards to be appropriate. In this way, risky and drastic changes that jeopardize the inherent identity of the product can be avoided.

The analytic framework applied in this study proved useful in analysing the constitutional and collective choice rules that shape the horizontal and vertical interactions of heterogeneous actors and the food quality standards they co-design. Three considerations emerge from our explorative analysis, which would benefit from an in-depth study of larger GI samples and other food quality systems: i) the more autonomy individual producer groups have, the greater the incentive to loosen food quality standards for short-term profits; ii) there is a trade-off between horizontal and cross-scale interactions and the time efforts required for adapting food quality standards; iii) these polycentric linkages support the long-term conservation of product identity and quality through broadly legitimised adaptations.

The policy implications of our findings need to be highlighted. Constitutional and collective choice rules need to be carefully designed, as they may affect the type and distribution of benefits that result from the protection of GIs, and also guide the evolution of products, their production systems and innovation pathways in the long term.

These lessons might be useful for policy makers in the current debate on the future of EU food policy. Indeed, the EU Commission has developed the "Farm to Fork Strategy" to ensure fair, sustainable, and competitive agriculture in the EU. Within this framework, one of the main reforms aims to improve the GI protection system to contribute to sustainable production, strengthen the position of farmers and GI producer groups in the food supply chain, and make the system more effective. The fragmentation of European legislation between Member States on some key issues is certainly a major problem. A lack of homogeneity may undermine the reputation of the system itself in the medium to long run. A better balance needs to be found between devolving tasks to Member States (and regions) and maintaining a strong identity for the GI system at EU level.

\section{Acknowledgments}

This research was supported by funds of the Oesterreichische Nationalbank: BOKU Vienna Open Access Publishing Fund (Central Bank of the Republic of Austria, Anniversary Fund, project number: 17043). We truly thank our interviewees for their time, exchange and expertise before, during and after the fieldwork. Furthermore, the authors are thankful for the valuable anonymous reviews. We are also grateful to Irene Konrad and Christina Roder for their editorial support.

\section{References}

Allaire, G., Casabianca, F., Thévenod-Mottet, E., 2011. Geographical origin: a complex feature of agro-food products. In: Barham, E., Sylvander, B. (Eds.), Labels of Origin for Food: Local Development, Global Recognition. Cabi, Wallingford, Oxfordshire, UK, Cambridge, MA, US, pp. 1-12.

Andersson, K.P., Ostrom, E., 2008. Analyzing decentralized resource regimes from a polycentric perspective. Pol. Sci. 41 (1), 71-93. https://doi:10.1007/s11077-007-90 55-6.
Baldwin, E., McCord, P., Dell'Angelo, J., Evans, T., 2018. Collective action in a polycentric water governance system. Environ. Policy Gov 28 (4), 212-222. https:// doi.org/10.1002/eet.1810.

Baritaux, V., Houdart, M., Boutonnet, J.P., Chazoule, C., Corniaux, C., Fleury, P., Lacombe, N., Napoléone, M., Tourrand, J.F., 2016. Ecological embeddedness in animal food systems (re-)localisation: a comparative analysis of initiatives in France, Morocco and Senegal. J. Rural Stud. 43, 13-26. https://doi.org/10.1016/j. jrurstud.2015.11.009.

Belletti, G., Marescotti, A., Touzard, J.M., 2017. Geographical indications, public goods and sustainable development: the roles of actors' strategies and public policies. World Dev. 98, 45-57. https://doi.org/10.1016/j.worlddev.2015.05.004.

Belletti, G., Canada, J.S., Marescotti, A., Vakoufaris, H., 2015. Linking protection of geographical indications to the environment: evidence from the European Union olive-oil sector. Land Use Pol. 48, 94-106. https://doi.org/10.1016/j. landusepol.2015.05.003.

Bérard, L., Casabianca, F., Montel, M.C., Agabriel, C., Bouchet, R., 2016. Salers Protected Designation of Origin cheese, France. The diversity and paradox of local knowledge in geographical indications. Cult. Hist. Digit. J. 5 (1), e006. https://doi.org/ 10.3989/chdj.2016.006.

Blomquist, W., 2009. Multi-level governance and natural resource management: the challenges of complexity, diversity, and uncertainty. In: Beckmann, V., Padmanabhan, M. (Eds.), Institutions and Sustainability. Springer Science+Business Media B.V., Dordrecht, the Netherlands, pp. 109-126.

Bowen, S., de Master, K., 2011. New rural livelihoods or museums of production? Quality food initiatives in practice. J. Rural Stud. 27 (1), 73-82. https://doi.org/10.1016/j. jrurstud.2010.08.002

Clark, L.F., Kerr, W.A., 2017. Climate change and terroir: the challenge of adapting geographical indications. J. World Intellect. Property 20, 88-102. https://doi.org/ 10.1111/jwip.12078.

Commission Implementing Regulation, 19.6.2014. (EU) No 668/2014 of 13 June 2014 laying down rules for the application of Regulation (EU) No 1151/2012 of the European Parliament and of the Council on quality schemes for agricultural products and foodstuffs. Orkesterjournalen L 179, 36-61. http://data.europa.eu/eli/reg_impl/ 2014/668/oj.

Creswell, J.W., Plano Clark, V.L., 2011. Designing and Conducting Mixed Method Research, second ed. Sage, Thousand Oaks, CA, US.

Edelmann, H., Quiñones-Ruiz, X.F., Penker, M., Scaramuzzi, S., Broscha, K. Jeanneaux, P., Belletti, G., Marescotti, A., 2020. Social learning in food quality governance - evidences from geographical indications amendments. Int. J. Commons 14 (1), 108-122. https://doi.org/10.5334/ijc.968.

Gläser, J., Laudel, G., 2010. Experteninterviews und qualitative Inhaltsanalyse, fourth ed. VS Verlag für Sozialwissenschaften, Wiesbaden, Deutschland.

Gugerell, K., Uchiyama, Y., Kieninger, P.R., Penker, M., Kajima, S., Kohsaka, R., 2017. Do historical production practices and culinary heritages really matter? Food with protected geographical indications in Japan and Austria. J. Ethn. Foods 4 (2), 118-125. https://doi.org/10.1016/j.jef.2017.05.001.

INAO (Institut national de l'origine et de la qualité), 2017. INAO Guide du Demandeur. 93555 Montreuil, France. Retrieved 28 October 2021, from. https://www.inao.go uv.fr/Espace-professionnel-et-outils/Produire-sous-signes-de-qualite-comment-faire /Guides-pratiques.

Mancini, M.C., Consiglieri, C., 2016. Innovation and marketing strategies for PDO products: the case of 'Parmigiano Reggiano' as an ingredient. Bio base Appl. Econ. 5 (2), 153-174. https://doi.org/10.13128/BAE-20087.

Marescotti, A., Quiñones-Ruiz, X.F., Edelmann, H., Belletti, G., Broscha, C., Altenbuchner, C., Penker, M., Scaramuzzi, S., 2020. Are Protected Geographical Indications evolving due to environmentally related justifications? An analysis of amendments in the fruit and vegetable sector in the European Union. Sustainability 12, 3571. https://doi.org/10.3390/su12093571.

Mariani, M., Cerdan, C., Peri, I., 2019. Contested knowledge: changing practices in origin-food communities. Br. Food J. 12 (12), 3011-3023. https://doi.org/10.1108/ BFJ-10-2018-0713.

Mariani, M., Cerdan, C., Peri, I., 2020. Origin food schemes and the paradox of reducing diversity to defend it. Sociol. Rural. 61, 465-490. https://doi.org/10.1111/ soru. 12330.

Marie-Vivien, D., Bérard, L., Boutonnet, J.-P., Casabianca, F., 2017. Are French Geographical Indications losing their soul? Analyzing recent developments in the governance of the link to the origin in France. World Dev. 98, 25-34. https://doi. org/10.1016/j.worlddev.2015.01.001.

McGinnis, D.M., 2011. An introduction to IAD and the language of the Ostrom workshop: a simple guide to a complex framework. Pol. Stud. J. 39 (1), 169-183. https://doi. org/10.1111/j.1541-0072.2010.00401.x.

Milestad, R., Darnhofer, I., 2003. Building farm resilience: the prospects and challenges of organic farming. J. Sustain. Agric. 22 (3), 81-97. https://doi.org/10.1300/ J064v22n03_09.

Millet, M., Casabianca, F., 2019. Sharing values for changing practices, a lever for sustainable transformation? The case of farmers and processors in interaction within localized cheese sectors. Sustainability 11 (17), 4520. https://doi.org/10.3390/ su11174520.

Morrison, T.H., Adger, W.N., Brown, K., Lemos, M.C., Huitema, D., Phelps, J., Evans, L., Cohen, P., Song, A.M., Turner, R., Quinn, T., Hughes, T.P., 2019. The black box of power in polycentric environmental governance. Global Environ. Change 57, 101934. https://doi.org/10.1016/j.gloenvcha.2019.101934.

Newig, J., Koontz, T.M., 2014. Multi-level governance, policy implementation and participation: the EU's mandated participatory planning approach to implementing environmental policy. J. Eur. Publ. Pol. 21 (2), 248-267. https://doi.org/10.1080/ 13501763.2013.834070. 
Nizam, D., Tatari, M.F., 2021. Rural revitalization through territorial distinctiveness: the use of geographical indications in Turkey. J. Rural Stud. https://doi.org/10.1016/j. jrurstud.2020.07.002 (in press).

Österreichisches Patentamt, s.a. Informationsblatt zum Schutz geografischer Angaben und Ursprungsbezeichnungen gemäß der Verordnung (EU) Nr. 1151/20121. Wien, Österreich. Abgerufen am 28. October 2021 von https://www.patentamt.at/ fileadmin/root_oepa/Dateien/Marken/Herkunftsangaben/HA_HA101_ Informationsblatt.pdf.

Ostrom, E., 2001. Vulnerability and polycentric governance systems. Newsletter of the International Human Dimensions Programme on Global Environmental Change 3 (2001).

Ostrom, E., 2010a. Analyzing collective action. Agric. Econ. 41 (Suppl. 1), 155-166. https://doi.org/10.1111/j.1574-0862.2010.00497.x.

Ostrom, E., 2010b. Beyond markets and states: polycentric governance of complex economic systems. Am. Econ. Rev. 100 (3), 641-672. https://doi.org/10.1257/ aer.100.3.641.

Ostrom, V., 1999. Polycentricity (Part 1). In: McGinnis, M. (Ed.), Polycentricity and Local Public Economics. University of Michigan Press, Ann Arbor, MI; US, pp. 52-74.

Pick, B., Marie-Vivien, D., 2021. Representativeness in geographical indications: a comparison between the state-driven and producer-driven systems in Vietnam and France. Sustainability 13, 5056. https://doi.org/10.3390/su13095056.

Polanyi, M., 1951. The Logic of Liberty: Reflections and Rejoinders. University of Chicago Press, Chicago, IL, US.

Quiñones-Ruiz, X.F., Forster, H., Penker, M., Belletti, G., Marescotti, A., Scaramuzzi, S., Broscha, K., Braito, M., Altenbuchner, C., 2018. How are food Geographical Indications evolving? - an analysis of EU GI amendments. Br. Food J. 120 (8), 1876-1887. https://doi.org/10.1108/BFJ-02-2018-0087.

Quiñones-Ruiz, X.F., Penker, M., Belletti, G., Marescotti, A., Scaramuzzi, S., Barzini, E., Pircher, M., Leitgeb, F., Samper-Gartner, L.F., 2016. Insights into the black box of collective efforts for the registration of geographical indications. Land Use Pol. 57, 103-116. https://doi.org/10.1016/j.landusepol.2016.05.021.

Regulation (EU) No 1151/2012 of the European Parliament and of the Council of 21 November 2012 on quality schemes for agricultural products and foodstuffs. Orkesterjournalen L 343, 14.12.2012, 1-29. http://data.europa.eu/eli/reg/2012/11 $51 /$ oj.

Reinecke, J., Manning, S., von Hagen, O., 2012. The emergence of a standards market: multiplicity of sustainability standards in the global coffee industry. Organ. Stud. 33 (5-6), 791-814. https://doi.org/10.1177/0170840612443629.
Rubin, H.J., Rubin, I.S., 2011. Qualitative Interviewing: the Art of Hearing Data. Sage, Thousand Oaks, CA, US.

Schouten, G., Bitzer, V., 2015. The emergence of Southern standards in agricultural value chains: a new trend in sustainability governance? Ecol. Econ. 120, 175-184. https:// doi.org/10.1016/j.ecolecon.2015.10.017.

Seawright, J., Gerring, J., 2008. Case selection techniques in case study research: a menu of qualitative and quantitative options. Polit. Res. Q. 61 (2), 294-308. https://doi. org/10.1177/1065912907313077.

Spiekermann, U., 2011. Redefining food: the standardization of products and production in Europe and the United States, 1880-1914. Hist. Technol. 27 (1), 11-36. https:// doi.org/10.1080/07341512.2011.548971.

Stoker, G., 2018. Governance as theory: five propositions. Reprint of the 1998 paper. Int. Soc. Sci. J. 68, 15-24. https://doi.org/10.1111/issj.12189.

Development of origin labelled products: humanity, innovation and sustainability. In: Sylvander, B. (Ed.), 2004. Dolphins WP7 Report. INRA-UREQUA (Institut National de la Recherche Agronomique - Unité de recherche sur l'économie des qualifications agro-alimentaires), Le Mans, France.

Tashiro, A., Uchiyama, Y., Kohsaka, R., 2019. Impact of Geographical Indication schemes on traditional knowledge in changing agricultural landscapes: an empirical analysis from Japan. J. Rural Stud. 68, 46-53. https://doi.org/10.1016/j. jrurstud.2019.03.014.

Teil, G., 2013. Is organic farming unsustainable? Analysis of the debate about the conventionalisation of the organic label. In: Bellon, S., Penvern, S. (Eds.), Organic Farming, Prototype for Sustainable Agricultures: Prototype for Sustainable Agricultures. Springer, Dordrecht, the Netherlands, pp. 325-344. https://doi.org/ 10.1007/978-94-007-7927-3 18.

Thiel, A., Moser, C., 2018. Toward comparative institutional analysis of polycentric social-ecological systems governance. Environ. Policy Gov. 28 (4), 269-283. https:// doi.org/10.1002/eet.1814.

Villamayor-Tomas, S., 2018. Polycentricity in the water-energy nexus: a comparison of polycentric governance traits and implications for adaptive capacity of water user associations in Spain. Environ. Policy Gov 28 (4), 252-268. https://doi.org/ 10.1002/eet.1813.

Vogl, C.R., Kilcher, K., Schmidt, H., 2005. Are standards and regulations of organic farming moving away from small farmers' knowledge? J. Sustain. Agric. 26 (1), 5-26. https://doi.org/10.1300/J064v26n01_03. 